\title{
The church as a social enterprise: A strategy for economic development
}

\author{
Linda Mabwe ${ }^{1}$, Caroline Dimingu ${ }^{2}$, Fairchild Siyawamwaya ${ }^{3}$ \\ Department of Accounting and Marketing \\ Zimbabwe Ezekiel Guti University, Bindura, Zimbabwe \\ Department of Theology and Religious Studies \\ Zimbabwe Ezekiel Guti University, Bindura, Zimbabwe \\ Department of Theology and Religious Studies \\ Zimbabwe Ezekiel Guti University, Bindura, Zimbabwe
}

\begin{abstract}
This article aims at establishing the role played by the church in sustainable development of Zimbabwe during a period of prolonged economic meltdown. It compares and contrasts the role of the missionaries' church and the modern day church in Africa and whether the church has not deviated from its main reason of existence. The study recognises the role the church is playing in today's economy and how the society and governments can optimise on its influence in various sectors. The article adopted the framework that was established by the European Economic and Social Committee in defining a social enterprise in their research on EESC recommendations on Social Enterprises (European Union: European Economic and Social Committee, 2014). A descriptive research design approach was used and both mainline and Pentecostal churches were used to draw on the conclusions. This research design heavily relied on secondary data gathered through literature review. The study concludes that churches are playing a significant role in developing the soicieties in which they are established hence contributing towards economic development. The study recommends the need for churches to identify areas of importance in the economy, such as the manufacturing industry, so that they channel resources towards establishing enterprises that improve the nation's Gross Domestic Product. Furthermore, the Zimbabwean government should provide special incentives for church run establishments to promote their operations. The study did not cover all churches hence the findings must be viewed in context and the conclusions were derived from the evidence gathered.
\end{abstract}

Keywords: Sustainable development, Social enterprises, Pentecostal, Church

\section{Introduction}

Zimbabwe, a landlocked country in Southern Africa has gone through various economic and political transitions since its inception to independence in the year 1980. The country had to deal with difficult numerous transitions in the area of politics, economics, public sector administration, national security, regional and international relations as well as social economic development (Kiggundu, 2002). Among these was a high youth unemployment rate which was once recorded at 68\% (Mukuhlani, 2014). Thirty-six years down the line, regardless of the economic meltdown, various churches are cropping up in a country, which was once the breadbasket of Southern Africa. Most of these churches are establishing various corporations and engaging social responsibility in the nation yet companies in the same environment are struggling to operate, some of them even closing down. It is against this background that in a time when the economy is facing challenges in various sectors, the church is managing to soldier on. The study compared the differnece in roles between missionaries and the modern day churches. It researched on the activities outside their church activities that the churches are engaging in and how these are contributing to economic development. It aimed at establishing the church as a social enterprise and why they are prospering whislst other organisations are heading the opposite direction. 


\section{Background and Context}

The role of the church in the development of the societies that they are established has become significant as there is an increasing recognition that inner city churches can play a leading role in motivating the residents of low-class locations to better themselves (Williams \& Bakam, 1992). Churches have always played a role in shaping the communities or rather societies in which they are established. In the $21^{\text {st }}$ century, the church that individuals belong to has a bearing on the circle of people they move around (Sivov, 2008). Sivov (2008) attests to that a number of institutions, ranging from hospitals, retirement homes and schools are relatively linked to churches where they get their support from thus placing the church at a very special position in a variety of countries when it comes to the provision of social services.

As supported by Williams and Bakam (1992) in their research, the church has had an impact upon a number of aspects of black American life through its central role in humanitarian activity of blacks. Williams and Bakam (1992), carried out a research on "the role of the church in community development" on two communities, the North Lawndale and Linwood Shopping Centre (LSC). The Lawndale Community Church (LCC) has embarked on three programs to reach out to the North Lawndale Community so as to bring community stability, and renewal, and to provide education, job skills and jobs to the people. The three programs were the Lawndale college opportunity program (LCOP), a housing program and an economic development project (Williams \& Bakam, 1992).

The LCOP catered for any student, regardless of religious affiliation, towards achieving their tertiary education qualifications thereby equiping them with a valuable asset of education and reducing crime rate. The LCC housing fund, supported by World Vision, acquired vacant or abandoned buildings, rehabilitates them and resells them to North Lawndale residents at affordable prices. This program program helped in the provision of cheaper accomodation, employment, community stability and community renewal. The economic development program created businesses that in turn created employment (Williams \& Bakam, 1992).

The Linwood Shopping Center in Kansas City, Missauri is a community development project that was as a result of the collaboration between the Black Baptist Ministers' Union of Kansas City and the Community Development Corporation of Kansas City. Its overall objective was to revatilize central city neighbours, increase community self-sufficiency by new jobs creation and the provisionof additional tax revenues for the area (Williams \& Bakam, 1992). The impact of this program was an increament in the workforce which resulted in economic growth, and it helped to increase business for other community enterprises thereby being a backbone for the develoment of the community (Williams \& Bakam, 1992).

A similar research to that of Williams \& Bakam (1992) was done in in Bulgaria by Sivov (2008), revealed that it has been the church that provided communal bonds that kept the nation together during the centuries of a practical absence of a national state. In the small village societies, in the times of the Bulgarian national revival (17-18th century), individuals started to self-organise in society centres and to set aside shares of their income for education. This action was carried out via church-driven institutions, referred to as cellschools and the reading rooms (Sivov, 2008). Evidently, the historic role of the church was not manifested only in the apparent meta-level of the abstract opinions of nation and faith. In those days, virtually all community life was somehow related to, focused in, or streamed out of the church (Sivov, 2008).

In the state of Bulgaria, the church has managed to find a distinct and extensive role in many aspects of public life in the beginning of the twentieth century. The local churches have proven to be effective vehicles of social change at a grass-roots level. Many religious groups started to structure their own small-scale charitable and educational programmes alongside the backing from international sources and local businesses. All this was oriented towards the needs of the local people showing that churches have turned to look at the necessities of the larger communities they are located in thereby creating the frameworks of a local social support network (Sivov, 2008).

Sivov (2008), identified four good reasons for non-religious national and community-centred NGOs to consider the churches as potential partners for long-term socially-related programmes. Firstly, the Church's ethos that is firmly engrained in the concept of the spiritual community. Secondly, the church has a division 
in virtually every settlement, both large and small. This makes it easily, one of the most usual partners for regional programmes, awareness-raising campaigns, and networking initiatives at a large-scale. Thirdly, the church has resources in the form of buildings and agricultural lands that can be engaged for national programmes for social integration or provision of social services. Lastly, serving the society within which a church is situated it is within its mandate, exclusive of discriminating anyone on grounds of age, gender, social status and religious belief (Sivov, 2008).

In South Africa, a research carried by Dreyer (2004) aimed at establishing whether there is prima facie evidence that the exclusion of the Church in works of development over the last three decades has had disadvantageous effects on the outcome of development. Evidently, it has been proven that the Church has an undisputed role to play in development work to improve social conditions for the benefit of the whole community. The Church, through the Scriptures, has a mandate to serve the poor as its responsibility (Dreyer, 2004). The study further revealed that once the Church has a clear understanding of both the origins of the complications in stimulating development work and the background and culture of the people involved. This gives the Church has the competency to make significant contributions, which are not within the capacity of various profane organisations (Dreyer, 2004).

Dreyer's (2004) research was centred on churches in Pietermaritzburg and Zimbabwe where the church has assisted several individuals to escape from the world's prospects of them and to win back the self-worth and self-respect which spring from a meaningful life with a meaningful purpose. It prove that the Church's involvement can benefit a community considerably.

In contrast, a study carried out by Ovbiedo (2013) on "The role of Christian churches in community development: A case study of Ovia South-west Nigeria" indicated that Christian churches in the society are not improving the quality of lives of its people economically, educationally and in terms of healthcare. In turn, it has an effect of increasing the rate of unemployment and poverty. This study revealed the lack of support from Christian churches with regard to the development of the community, and showed that there is a need for Christian churches to contribute to the development of the community (Ovbiedo, 2013). The findings of this study indicate that the Christian churches in this community are not living up to the expectations of the societies they are established.

Christian missionaries found their way into the Zimbabwean economy long before the country became colonised by Britain in 1890 and established numerous mission stations and schools and converted thousands of Africans to Christianity. For much of this period, the major denominations represented in the country were the well-known traditional ones, such as the Anglicans, Roman Catholics, and Methodists, among others. The missionaries played a very crucial role in Africa during the colonization period in bringing the gospel of Christianity to the black society, as well as educating the indigenous community. The twentienth century has witnessed the birth of churches of various denominations, which were no less than 220 different denominations by the mid-1980s, despite the economic meltdown that the country went through during the past decades ( Madise, 2009).

The twentienth cemtury church in Zimbawehas taken on another role than just that of buiding communities spiritully due to the activities that they are engaging as pillars to their structures. Today churches have multiplied all over the world and are globalising more than co-operates due to their place in society. Churches in Zimbabwe have taken a different approach from the missionaries in how they engage in various activities. The economic meltdown has actually provided a hub for the creation of more churches in Zimbabwe to engage in the gospel of prosperity. However, with the sprouting of these churches came along a light of hope for the various Zimbabweans in destitute due to the tough economic conditions. The study was centred on the case studies of two churches, the Roman Catholic Church representating the traditional churches and the Zimbabwe Assemblies of God in Africa (ZAOGA) Church representing the pentecostal churches. The following are some of the activities that the two churches are engaging in.

\section{The Roman Catholic Church}

The Roman Catholic Church has various establishments branching out of its church and they have different mandates. These are illustrated in the diagram below: 


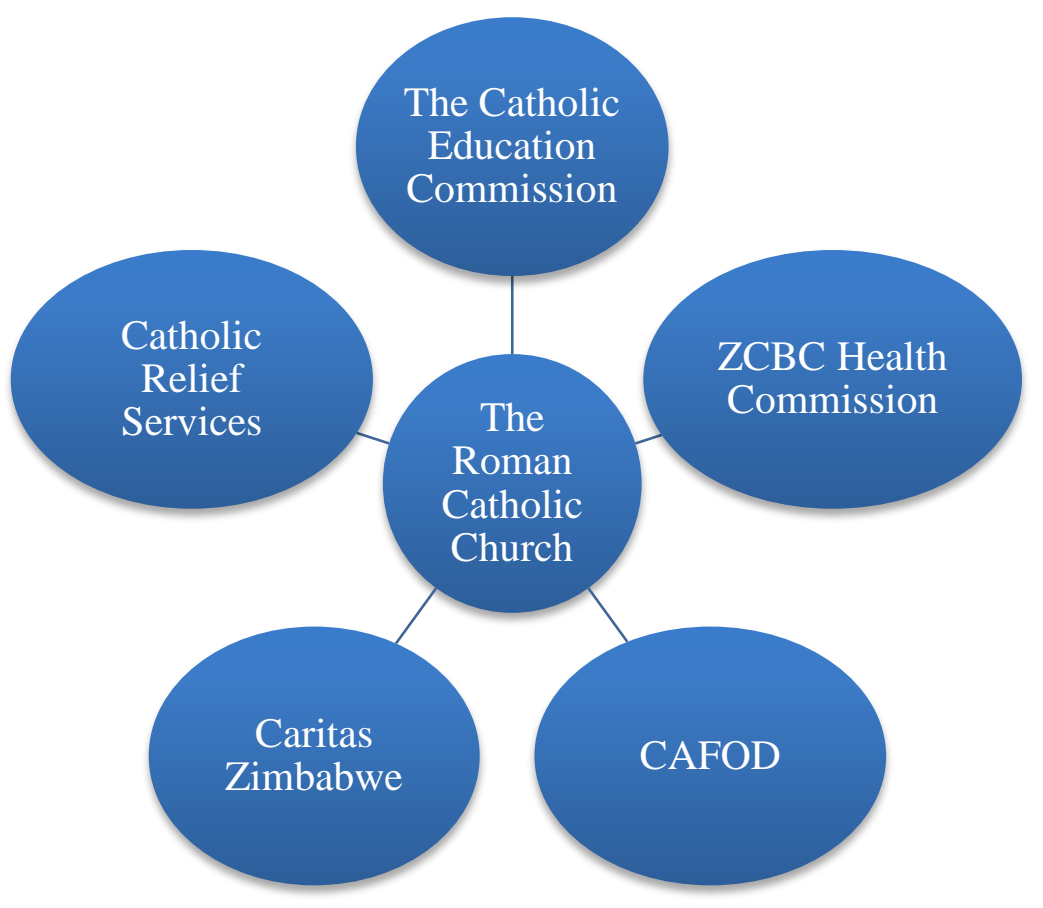

\section{Source: Raw Data}

\section{The Catholic Education Commission}

The Catholic Education Commission of the Zimbabwe Catholic Bishops Conference (ZCBC) exists to offer a service on the other one hand to the members of the Conference itself, and on the other hand, to the responsible authorities, primary and secondary schools, teacher training colleges and all those persons and institutions engaged in the work of catholic education in Zimbabwe (Zimbabwe Catholic Bishops Conference, 2016). The Commission is directed by the ZCBC Education Secretary in liaison with the diocesan education secretaries and the education delegates of the conferences of Major Religious superiors, who are the members of the commission, and any other person(s) whom it may be considered appropriate to co-opt from time on time.The Catholic Education Commission has established approximately 196 schools from the colonial era to date. The distribution of the schools is as follows:

\section{Table 1: Schools under The Catholic Education Commission}

\begin{tabular}{|l|l|}
\hline Archdiocese & Schools \\
\hline Harare & $\begin{array}{l}\text { A number of Pre-Schools, 21 Primary Schools, 20 Secondary Schools, } \\
\text { one tertiary Catholic university. }\end{array}$ \\
\hline Bulawayo & $\begin{array}{l}10 \text { Pre-schools, 13 Primary Schools, 10 Secondary Schools and 3 } \\
\text { Tertiaries }\end{array}$ \\
\hline Chinhoyi & 2 Pre-schools, 4 primary schools, 4 secondary schools and one tertiary \\
\hline Gokwe & Several pre-schools, 5 primary schools 6 secondary schools \\
\hline Gweru & $\begin{array}{l}\text { 13 Primary Schools, 10 Secondary Schools, pre-schools and a number } \\
\text { of Vocational training intuitions }\end{array}$ \\
\hline Hwange & $\begin{array}{l}\text { Several pre-schools, 6 primary schools and one secondary school and } \\
\text { several vocational training centers }\end{array}$ \\
\hline Masvingo & $\begin{array}{l}\text { Several pre-schools, 12 primary schools, 11 secondary schools and } \\
\text { one tertiary institute. Below are the addresses of the schools }\end{array}$ \\
\hline Mutare & $\begin{array}{l}\text { Several pre-schools, 20 primary schools, 22 secondary schools and } \\
\text { various vocational training centers }\end{array}$ \\
\hline
\end{tabular}

Source: http://www.zcbc.co.zw/catholic-education-commission/ 
The Inspiration for the work of the Catholic Education Commission comes from the command of our Lord Jesus Christ to "go out and teach all the nations". To carry out her saving mission, the church uses, above all, the means which Jesus Christ has given her. She also uses other means which at different times and in different cultures have proved effective in achieving and promoting the developments of the human person. The Church adapts these to the changing conditions of emerging needs of mankind. In her encounter with differing cultures and with man's progressive achievements, the church proclaims the faith and reveals to all ages the transcendent goals which alone gives life its full meaning. She establishes her own schools because she considers them as a privileged means of promoting the formation of the whole man, since the school is a centre in which a specific concept of the word of man and of history is developed and conveyed (Zimbabwe Catholic Bishops Conference, 2016).

\section{ZCBC Health Commission}

The vision of the ZCBC Health Commission exitsts to provide affordable, quality and accessible Health Care to all, especially vulnerable groups, that uphold their dignity. It offers pastoral care that meets the spiritual, physical, social and emotional needs of the person as a whole as well as coordinating and collaborating with the MOHCW and other health service providers. Above all, the Commission mobilizes resources and assesses the church's response and impact on society. The Commision has forty-two (42) hospitals and nine (9) clinics whose distribution are illustrated below:

\section{CAFOD}

CAFOD is a Catholic owned organisation that has been supporting programmes in Zimbabwe for more than 30 years, predominantly through the Catholic Church in partnership with other organisations that are part of the ZCBC. Its work focuses on provision of assistance to support groups for people living with HIV and AIDS and those affected by the pandemic. The organisation does this through sourcing resources to boost income, nutrition tips and healthy behaviour advice for the people. In addition, CAFOD trains the victims skills in farming, providing seeds and tools to vulnerable families - enabling them to reduce their dependency on food handouts (CAFOD, 2016).

\section{Caritas Zimbabwe}

Caritas Zimbabwe is a member of Caritas Internationalis (CI), a worldwide federation of the Catholic Church relief and development organisations. The organisation was established in 1972 as a development initiative and also responds to the emergency situation that prevailed in the country at the time that a liberation war was being fought (CARITAS , 2016). Its purpose is to carry out community developmental and humanitarian work involving the deprived children, their families and communities in order to improve their economic and social conditions. Catholic Church's social teachings are the basic foundation of the organization (Zimbabwe Catholic Bishops Conference, 2016). Caritas Zimbabwe is currently working in 8 Program dioceses with a total country caseload of over 245,000 beneficiaries. Some of the programs include the Emergency Relief Program that seeks to restore human dignity with love by responding to needs of victims of various calamities regardless of creed, race, gender, ethnicity or other social grouping. Includes refugees, internally displaced people (IDPs), orphans \& vulnerable children (OVCs) (Zimbabwe Catholic Bishops Conference, 2016).

\section{Catholic Relief Services}

Catholic Relief Services, an organisation administered by a Board of Bishops selected by the Episcopal Conference of the United States, was founded in 1943 by the Catholic Bishops of the United States to assist the poor and disadvantaged. In Zimbabwe CRS was established in 1989 and it is staffed by men and women committed to the Catholic Church's mission of helping those in need (Kubatana, 2013). The CRS activities pertains to the alleviation of human suffering, the development of people and the fostering of charity and justice in the world. The policies and programs of the agency reflect and express the teachings of the Catholic Church. Catholic Relief Services assists persons on the basis of need not creed, race or nationality although it draws its basic financial, material and moral support from the Catholic community in the United States. It also reaches out for support to individuals of many faiths and to government and community organizations, foundations, corporations and to student groups (Kubatana, 2013). 


\section{The Zimbabwe Assemblies of God Church in Africa (Forward in Faith Ministries)}

Zimbabwe Assemblies of God Africa (ZAOGA) is a large Pentecostal church known internationally as Forward in Faith Ministries International (FIFMI). As of 2000, there were 4,000 congregations and 539,683 members. ZAOGA is divided into 26 provinces in Zimbabwe. The movement was founded in the late 1950s by a group of Pentecostals from the Apostolic Faith Mission who gathered around the charismatic Ezekial $\mathrm{H}$. Guti who continues to lead the church. Zimbabwe is the location of the ZAOGA-FIF headquarters and the host-nation of a number of international gatherings for FIFMI.

\section{Figure 2: Institutions owned by ZAOGA FIFMI}

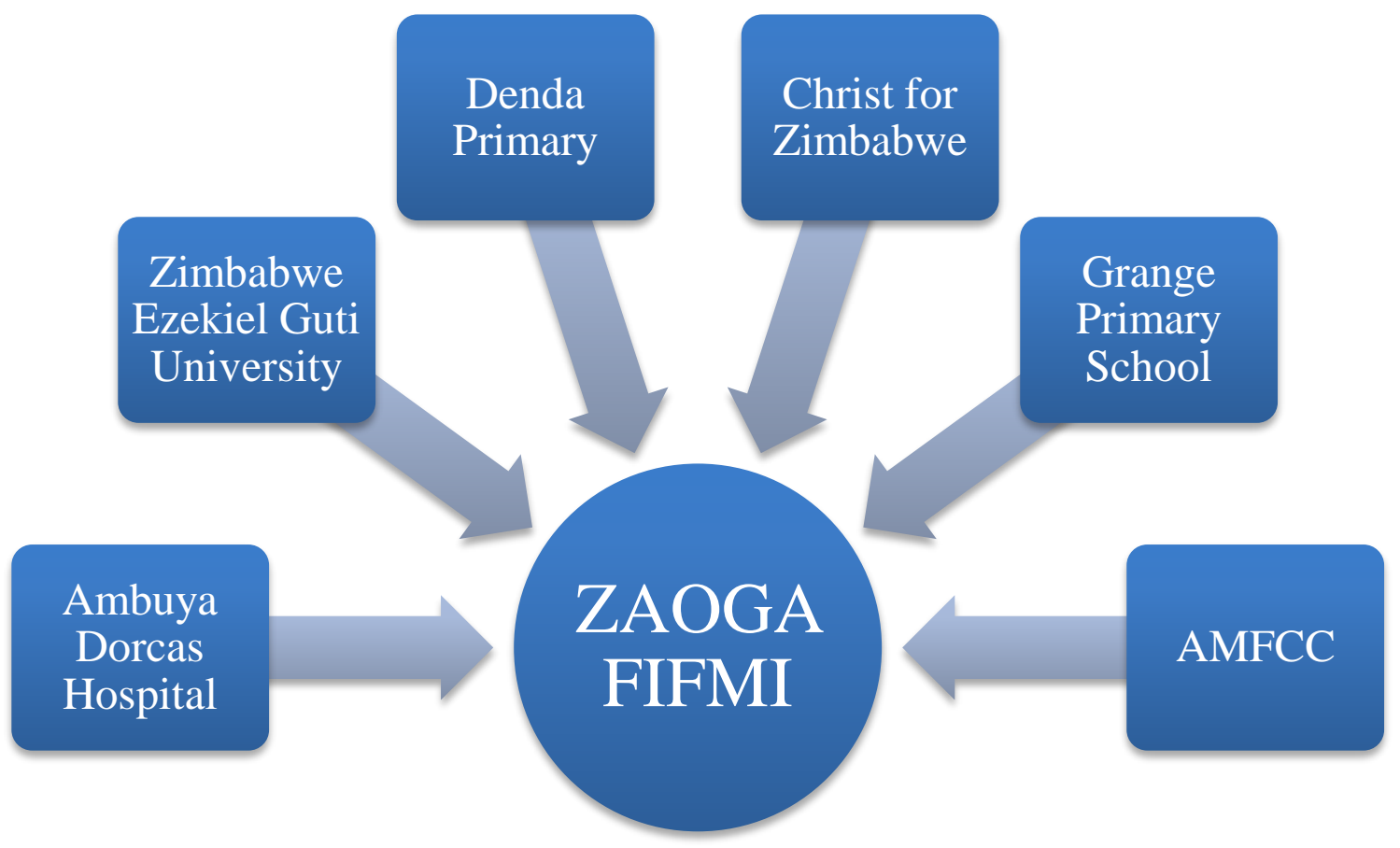

\section{Source: Raw Data}

\section{Contribution of FIFMI to the Education Sector}

ZAOGA has schools in Zimbabwe including Grange Primary School in Chisipite which is a state of the art school, Denda Primary in Mutoko, Christ for Zimbabwe High School, a children's home in Mutare, as well as three bible schools in Harare, Chiredzi, and Bulawayo.

\section{The Zimbabwe Ezekiel Guti University (ZEGU)}

ZEGU, a brainchild of the founder of ZAOGA F.I.F, Professor Ezekiel Handinawangu Guti, currently the Chancellor for the University, is a private Christian University, which started in May 2012 (ZEGU, 2016). It is a university accredited by the Zimbabwe Council of Higher Education (ZIMCHE) that creates an opportunity for the development of minds, hearts and hands in the fear of God. ZEGU has an academic thrust of entrepreneurial development in its endeavor to develop a total person who can bring solutions to the planet (ZEGU, 2016). The vision of ZEGU is to be a leading research intensive, globally connected Christian University producing solution-driven, innovative and enterprising graduates. It exists to offer a conducive learning environment for the development of entrepreneurial skills; preparing students to provide fully to humanity as globally engaged citizen leaders; advance outreach, commitment and economic development activities that are innovative, research driven and lead to an improvement in the quality of life for individuals and the society (ZEGU, 2016).

\section{Contribution of FIFMI to the Health Sector}

In May 2012, ZAOGA FIFMI built the Mbuya Dorcas Health Centre in Waterfalls. This medical institution also has a non-medical unit where those with spiritual needs will be ministered to through prayer and the Word. This is a fully-fledged and equipped world class hospital that was funded totally by ministry members through the working of Talents and giving to the kingdom of God (FIFMI, 2011). The hospital has a 
commercial pharmacy called Balm Pharmacy which has already opened and is already serving the community, with excellence and the love of Christ to the Glory of our heavenly Father.

Besides the pharmacy the hospital has many wards and houses for effective services. Just to note a few, the health centre has an Administration block, which will house all the management and accounting for the hospital. The Casualty Department is the first section of the Hospital that has a beautiful appearance and many world class standards and equipment. This section of the health centre is scheduled to open first then the children's ward will follow. The hospital also has the main ward, which will host the private wards, male and female wards.

MDHC is a Christian hospital and it puts Jesus Christ and the power of the Holy Spirit first, as it is by his strips we are healed. Having said this there is also a nun-medical section of the hospital that deals with praying for the sick in body and soul. In many cases in the medical industry, doctors meet medical cases that cannot be explained by scientific means and at MDHC the doctors just need to refer the patients to the nunmedical section of the hospital where the Lord will directly touch and heal the sick through his servants who will be present to be use of him.

There are many staff houses and doctor's accommodation at the hospital allowing the centre to run 24 hour a day 7 days a week. Headed by Matron Mrs. T. Joseph, employing highly qualified stuff ready to serve people and the Lord through the great project that the Lord put on this servant Apostle Dr.Ezekiel. H. Guti.

\section{Conceptual Framework}

The researcher adopted the framework that was established by the European Economic and Social Committee in defining a social enterprise in their research on EESC recommendations on Social Enterprises. The EESC adopted a description based on shared characteristics so that efforts could be focused (European Union: European Economic and Social Committee, 2014). It identified the following characteristics for the description of a social enterprise:

- Having primarily social objectives as opposed to profit objectives, producing social benefits that serve the general public or its members;

- Being primarily not-for-profit, with surpluses principally being reinvested and not being distributed to private shareholders or owners;

- Having a variety of legal forms and models: e.g. cooperatives, mutuals, voluntary associations, foundations, profit or non-profit companies; often combining different legal forms and sometimes changing form according to their needs;

- Being economic operators that produce goods and services (often of general interest), often with a strong element of social innovation;

- Operating as independent entities, with a strong element of participation and co-decision (staff, users, members), governance and democracy (either representative or open);

- Often stemming from or being associated with a civil society organisation.

These characteristics are illustrated in the diagram below:

Figure 3: Characteristics of a Social Enterprise 


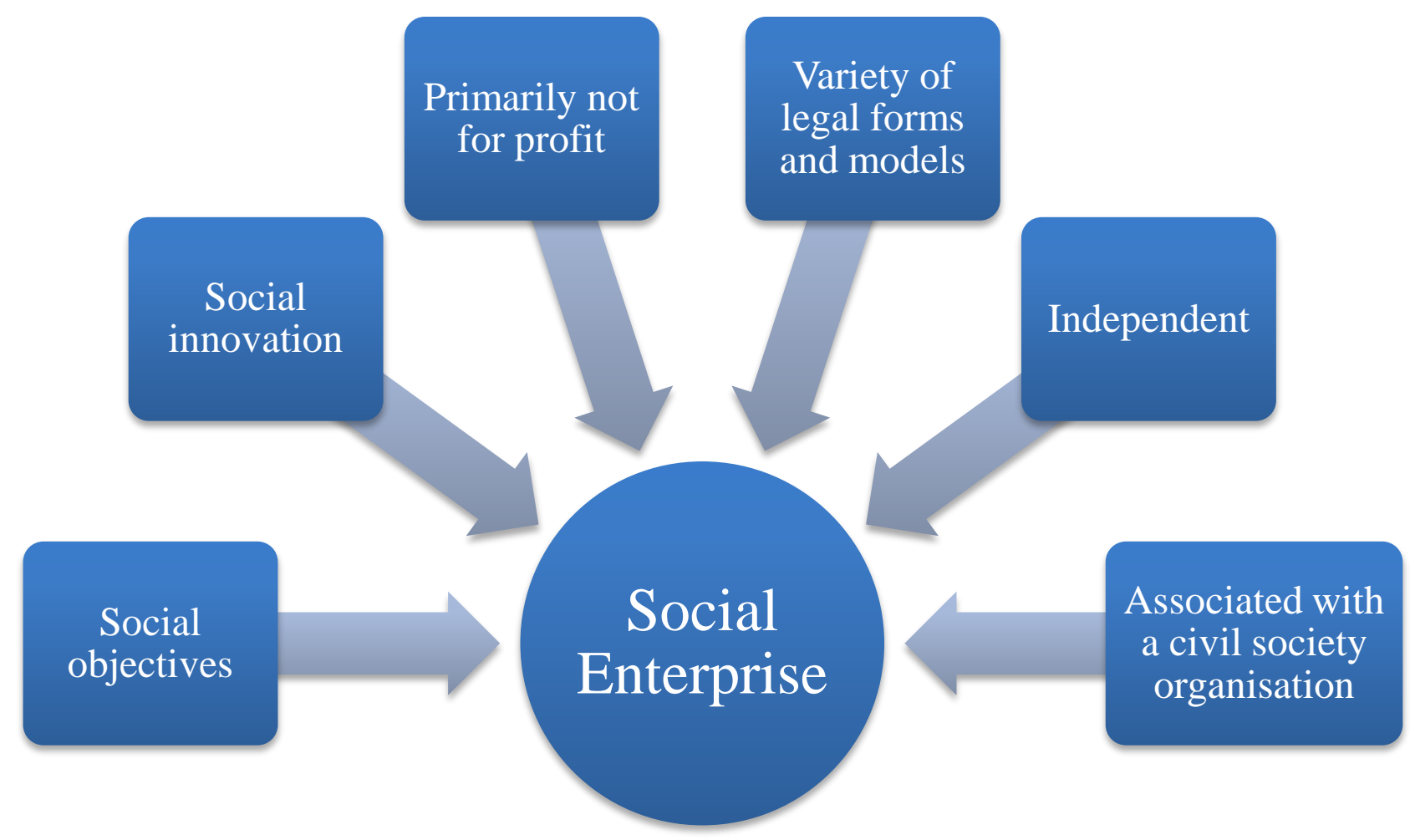

\section{Source: European Union: European Economic and Social Committee (2014)}

\section{Literature Review}

Lynch and Walls (2009) define a social enterprise as a business that seeks, above all, to make the world a better place, a business for the common good. The two derived the definition from the purpose or mission of the enterprise. At the most basic level, the test of the value of any social enterprise would be the extent to which it would be missed if it was no longer there (Denny \& Seddon, 2013). Social enterprises are commonly becoming popular for their contributions to the local community in addition to all of the benefits that they bring to their parent non-profit organisations. Some of the benefits of social enterprises highlighted by Holcomb and Fox Parker (2014) include:

Addressing Environmental Issues - these include recycling, ecotourism, education, etc.

$>$ Stimulating Economic Revitalization - social enterprise has become a key component of economic diversity and community development.

$>$ Poverty Reduction: social enterprises help reduce poverty through the provision of training, skills, resources and opportunities for individuals to earn a living wage.

> Provision of Accessible Health Care - social enterprises have become a hub for affordable and accessible health care support for rural residents, immigrants, low-income families, and seniors, amongst others.

$>$ Provision of services and products to an underserved community - social enterprises in many societies are often the most effective and efficient service providers.

$>$ Developments of social and cultural capital - social enterprises increase the social and cultural capital of the communities they are based in thereby strengthening relationships between different groups of individuals.

The most common resemblances amongst social enterprises are the presence of a parent non-profit. A parent non-profit is a non-profit organization that is actively involved in the planning, creation and operation of a social enterprise that shares a similar social mandate. Parent non-profits usually provide start-up finances; initial staffing resources, business plan development support, and stakeholder connections (Holcomb \& Fox Parker, 2014). Social enterprises are organizations with primarily social objectives whose surpluses are mainly reinvested for that purpose in the business or in the community, rather than being driven by the need to maximize profit for shareholders and owners (Dinham , 2007). 
Social enterprises have a range of organizational forms, which also have a range of legal forms (Floyd, 2012). They can adopt whichever legal structure is best suited to meeting their goals, though half the time they also have charitable status. The most common legal forms include co- operatives and community benefit societies, community interest company (CIC) and limited liability companies, just to mention a few (Floyd, 2012). The multiplication of international organizations and the active shaping and acceptance of social enterprises through them, has given rise to a mixture of organization forms providing social welfare within the European countries. These include sole-proprietorships, public bodies and affiliates among others (Lehner, 2011).

To date, only a few nations have implemented a special legal form for social enterprises such as the CIC, examples include the Community Interest Company in the UK, and in Italy, the L3C in the US, a low-profit limited liability company tailored for social enterprises (Lehner, 2011). The legal framework becomes very important when issues such as tax-deduction and exemption, access to equity capital, participation of employees and stakeholders, dividend payouts and the ability to receive grants are raised (Lehner, 2011). In countries such as Austria, there is the 'gemeinnu "tzige', $\mathrm{GmbH}$, which offers some tax alleviations to the traditional non- profit organizations (Lehner, 2011).

However, engaging into a social enterprise doesn't necessarily entail changing the legal structure of any company, as a variety of options are available dependent on the nature of the activities an organization carries out as well as the size of organization (Floyd, 2012).

Social enterprises tackle social and environmental challenges, creating employment while prioritizing impact over profit. In contexts of deep social problems and high unemployment, social enterprise models can concurrently contribute to employment creation and economic development at the same time addressing social and environmental problems (Darko \& Koranteng , 2015).

Social enterprises also trade products and services to promote social and environmental goals as they are led by a sense of social purpose. Mainly, the aim is to deliver social benefits and tackle intractable social problems. Social aims include employment creation; provision of goods and services to consumers; tax payments in turn supporting public services; donating to charities and foundations, and so on (Leadbeater , 2007). Examples of social enterprises include the Sari UK, which recycles discarded saris to create fashionable products and reinvest them in developing countries; the CaféDirect, that pays above market rates for coffee, tea and cocoa growers to aid development; the Fifteen Foundation that aids the under-privileged youth to acquire training and jobs in the catering industry; and the Furniture Resource Centre in Liverpool that offers employment to people disconnected from the mainstream economy to recycle unwanted furniture which it trades (Leadbeater, 2007).

Stakeholder groups such as users, employees, clients, social investor and local community groups base governance and ownership structures of a social enterprise on participation (Dinham , 2007).

Social enterprises can also stem from a certain civil organisation which usually manners the way in which the organisation runs. This is a positive way of to increasing the social impact of the organization without changing its core activities. In addition, an organization can set up a business that has no direct link to its social mission but generates revenue that can be spent on fulfilling its social mission (Floyd, 2012).

The Salvation Army, a Christian Church, registered charity with over 50,000 members and over 4,000 employees in the UK, runs several organizations across, described as 'a spectrum of social enterprise'. This includes a bank, an insurance company and the Salvation Army Trading Company Ltd (SATCoL), a business that operate on a commercial basis to generate revenue for the organization (Floyd, 2012). The organization also operates charitable services on a socially enterprising basis, which are the EmploymentPlus and Homelessness services (Floyd, 2012).

\section{Research Design and Methodology}

The study adopted the descriptive study approach as the purpose was to identify, describe and answer what is/who, what, when, where and how questions, it is a more restricted purpose. This fit well with the purpose of this study in that answers to how a church fits into the definition of a social enterprise. The research 
adopted the qualitative research design. In order to understand how perceptions are created and given meaning, the researcher had to interact with the church members in their operations as opposed to controlled laboratory experiments. This study aimed to establish the church as a social enterprise and explore the activities that the church is engaging in outside its church activities.

The study covered churches from Harare, specifically those carrying on business in Harare Metropolitan Province and Bindura. Harare was chosen because it is the capital city with so much economic activities and thus plays host to major churches. Harare was also targeted because most of the headquarters of the churches operate from there. Bindura was chosen because of its convenience to the researcher.

In this study purposive and convenience-sampling process were adopted as each church was considered to be engaging in distinct activities. To ensure the richness of the interview data, participants from various churches were identified and selected. About 150 questionnaires were distributed to church members. The study made use of focus groups with two groups of participants, church and community members. This interview technique was chosen as it allowed the researcher to ask probing questions to gather data on the activities that the church engaged in and why..

A structured questionnaire was also used to collect data in this study. The questionnaire contained both closed and open-ended questions. There were also categorical responses that offered respondents two options of yes or no. Categorical questions had follow-up questions that intended to probe more elaborate explanations about a variable under focus.

Consent forms were used in this study with questionnaire cover letters where participants had to sign as a way of voluntary consent for participation in the study. The purpose of this study was to establish the church as a social enterprise and explore the activities that the church is engaging in outside its church activities.

\section{Results and Discussion}

From the study, $64 \%$ were below the age of $40 ; 68 \%$ female; $24 \%$ were single; $46 \%$ were married; $24 \%$ were; $18 \%$ single parents and $12 \%$ divorced. $8 \%$ had at least primary education; $10 \%$ ordinary level; $16 \%$ advanced level, $66 \%$ academic qualifications; $42 \%$ were formally employed. These findings suggest that the respondents are mostly females of a productive age, have at least a primary education, and less than $50 \%$ have secure sources of income. The level of unemployment amongst the respondents of $58 \%$ is a common issue in Zimbabwe due to the economic meltdown as cited by Madise (2009).

The literature suggests that the institutions established by the two churches are not strictly benefiting the church members but the society as well. The respondents' views of the activities of churches were that they lead to a greater extent to the social development of the societies they are established. $90 \%$ of the respondents indicated that churches have reduced the bad behaviour of the youth, especially in high-density suburbs. The youth are now becoming more respectful from the churches as well as contributing to the reduction of violence in the community. Evidently, it shows that the teachings of the churches are transforming the lives of the citizens of the community hence they are playing a vital role in the social development of the community. However, the activities of the churches do not directly lead to the development of other sectors such as economic development.

From the findings, it clearly reflects that the majority of the respondents had at least primary education and the churches are playing a significant role in the provision of education as identifies from the literature were the churches have built schools in the country ranging from kindergarten to tertiary education. Furthermore, the establishment of schools from churches ensures the educational growth of the community. At tertiary level, some of the students receive scholarships at the tertiary institutions to complete their education. With regard to the healthcare system, the research found out that $68 \%$ of the respondents agreed that the churches were helping in terms of healthcare through the establishment of hospitals around the country. This is supported by the literature above were the ZCBC Health Commission, under the Roman Catholic Church has forty-two (42) hospitals and nine (9) clinics whilst the ZAOGA Forward in Faith Church has recently opened the Mbuya Dorcas Hospital. 
Of the respondents, $88 \%$ are of the view that the churches have assisted their church members to create employment for themselves through various activities within their churches though these are not regarded as formal employment. Special mention was made to the ZAOGA Forward in Faith school of talents that has helped its church members to be self sufficient through teaching them entrepreneurship skills. This has helped in the reduction of criminal activities within the society. Unemployment is one of the major problems that Zimbabwe is facing as an economy.

However, $48 \%$ of the respondents disagreed that the churches helped the poor by giving them food, clothes and money as they were of the view that the churches are only interested in enriching themselves through collection of offerings and tithes, even if there is no improvement in the economic life of the people in the society.

The findings evidently show that the churches in Zimbabwe are attempting to alleviate the social and economic problems that the communities in Zimbabwe are facing. This is being done through the establishments of institutions around the country in the education and healthcare areas, as well as other social establishments such as orphanages. The churches are also channelling efforts towards the betterment of the lives of the citizens within the community through teachings and promoting entrepreneurship activities. The study also revealed that the institutions established by the churches are supported by the churches themselves, regardless of whether profits are being made or not. This evidently shows that the church is not thriving to make profits from these establishments but rather improve the livelihoods of the community they are in.

The research also revealed that the various institutions that were established by the churches had primarily social objectives as opposed to profit objectives, thereby producing social benefits that serve the general public. This is evidenced by the various reasons why the institution were established from the research. The ZCBC Health Commission exitsts to provide affordable, quality and accessible health care to all, offering pastoral care that meets the spiritual, physical, social and emotional needs of the person (Zimbabwe Catholic Bishops Conference, 2016). CAFOD focuses on provision of assistance to support groups for people living with HIV and AIDS and those affected by the pandemic through sourcing resources to boost income, nutrition tips and healthy behaviour advice for the people (CAFOD, 2016). The Catholic Relief Services activities pertains to the alleviation of human suffering, the development of people and the fostering of charity and justice in the world (Kubatana, 2013). CARITAS exists to carry out community developmental and humanitarian work involving the deprived children, their families and communities in order to improve their economic and social conditions (CARITAS , 2016). All these visions reflect that the establishmnets there to promote social objectives as opposed to profit motives.

The study revealed that institutions that were established by the churches are primarily not-for-profit, with surpluses principally being reinvested and not being distributed to private shareholders or owners. This is reflected from the various establishments being run by the ZAOGA Forward in Faith church were the money is reinvested into the institutions. The infrastructer from the institutions from the the ZAOGA church are built by the members of the church through what they term 'talents' as sighted by Musoni. The members of the church also help in the payment of salaries and working capital required to run these institutions.

The various establishments from the church are of different legal forms such as schools, colleges, universities, clinics, hospitals and voluntary associations, all non-profit companies that combine different legal forms. The research findings reveal that organisations under the Roman Catholic Church are of different legal form such as CAFOD, Caritas and CRS, just to mention a few. This is also similar to the institutions running under the ZAOGA Forward in Faith Church.

However, in relation to the establishments being economic operators, the study revealed that the institutions established by the churches are mainly into the provision of services rather than goods, that is, schools, clinics, hospitals and voluntary organisations. These services have a strong motivation from the societies that they are established in. The Zimbabwe Ezekiel Guti University was established so as to produce graduands who are termed 'a total person', individuals who have their minds developed as well as developed spiritually. Graduands who are not corrupt and whose aim is to improve the society they are in, who are not just motivated by money. 
The study revealed that the organisations established by the churches operate independently and they try to stand on their own regardless of the times that they get assistance from their donor churches. However, they overally report to he church their activities. The schools and healthcare centres that were established by the catholic church are run by qualifies vocational principals from the church who report dually, both to the church and the ministries they belong to as they have to adhere to certain legislations.

The findings also revealed that the church run establishments would always belong to the church even if their services do not discriminate. ZEGU is a Christian Institution owned by ZAOGA FIFM but it employs individuals from all walks of life and the students are also from different backgrounds which is also similar to the Roman Catholic establishments. For example, as cited above, the Catholic Relief Services assists persons on the basis of need not creed, race or nationality although it draws its basic financial, material and moral support from the Catholic community in the United States. It also reaches out for support to individuals of many faiths and to government and community organizations, foundations, corporations and to student groups (Kubatana, 2013). This shows that its social mission does not choose but rather wants to fill a gap in the communities. This supports th e research done by Darko \& Koranteng (2015) on Social Enterprise Landscape in Ghana, where the authors idetified that social enterprise models can concurrently contribute to employment creation and economic development at the same time addressing social and environmental problems in contexts of deep social problems and high unemployment.

\section{Policy Options, Recommendations and Practical Implications}

The study has revealed literature of how churches in other nations are contributing to the social and economic development of their economies and the policies that have been put by the governments to ensure their smooth operations. Policy makers in the government have an important role to paly in promoting the activities of the churches so as to further their contributions. An important point to note is the creation of policies that facilitate the growth of church establishments around the country to encourage more investment by the church.

The government should ensure that policy issues relating to creating the conditions that support the joint ventures between non-government organizations and churches are created so as to incentivize the creation of more establishments by the church. This is in support of the research carried out by Sivov (2008) that identified four good reasons for non-religious national and community-centred NGOs to consider the churches as potential partners for long-term socially related programmes. One of the reasons was that, serving the society within which a church is situated it is within its mandate, exclusive of discriminating anyone on grounds of age, gender, social status and religious belief (Sivov, 2008). This guarantees continuity of these establishments even if the NGOs leave the country, the churches will guarantee the continuity of the existence of the establishments.

The government should engage the church community when partaking in poverty reduction programs, creating policies to encourage and facilitate different forms of interaction between the church and various captains of industry in the environment. This in turn encourages more religious groups to engage in activities that promote the community that they are in as well as growth of the already established institutions.

The government should also introduce policies that offer tax alleviation to religious organizations that are evidently making impact to the communities they are located. An example is that of the 'gemeinnu "tzige', $\mathrm{GmbH}$ in Austria, which offers some tax alleviations to the traditional non- profit organizations (Lehner, 2011). Something can also be introduced to church establishments in Zimbabwe.

A special legal form for social enterprises should also be introduced so as to promote such activities from the church and to make it easier for the churches to claim their benefits. The legal framework becomes very important when issues such as tax-deduction and exemption, access to equity capital, participation of employees and stakeholders, dividend payouts and the ability to receive grants are raised (Lehner, 2011). Policies should be developed to encourage and aid SME development in developing countries through church-community partnership. 
The church established institutions should maintain control over the supervising and evaluative process, the planning of revenue generating activities, implementation and costs. This is fundamental to ensure viable and decision-based development, which in turn promotes evaluation. Last but not least, the churches should also attempt to also engage in the provision of products that directly contribute to economic development so as to have a positive impact on the GDP of the economy.

\section{Conclusion}

The findings in the study have revealed that the church qualifies to be a social enterprise in the current environment, as it has satisfied all the characteristics from the conceptual framework. The churches are now establishing institutions that are offering services that are satisfying the social needs of the Zimbabwean context.

Further studies are required to wholly evaluate the scale of the impacts of the activities of religious based organizations and their impact on sustainability. The contribution from church based organizations is continuously becoming essential as they are playing an increasing role in the social development of the societies they are situated. More in-depth research, may also be required on the role of the church on the development of SMEs as the economy is increasingly relying on them for employment.

\section{References}

[1] Social Value Lab 2015, 'Social Enterprise in Scotland: Census 2015', Social Value Lab, Scotland.

[2] Mukuhlani, T 2014, 'Youth empowerment through small business development projects in Zimbabwe: The case of Gweru Young People's Enterprise (GYPE)', JSDA Volume 16 (5), pp. 138144.

[3] Kiggundu, MN 2002, Managing Globalization in Developing Countries and Transition Economies: Building Capacities for a Changing World, Greenwood Publishing Group, United States.

[4] Zimunya \& Gwara, J 2013, 'Pentecostalism, Prophets and the Distressing Zimbabwean Milieu' in Chitando, E, Gunda, R.M and Kugler, J. (eds), Prophets, Profits and the Bible in Zimbabwe. , University of Bamberg Press, Bamberg.

[5] Orts, W 2015, Business Persons: A Legal Theory of the Firm, Oxford University Press.

[6] Goodman, 1995, The Origins of the Western Legal Tradition: From Thales to the Tudors, Federation Press.

[7] Oham, 2015, 'Faith-Based Social Enterprise Capacity Building Study', Oxford University Innovation Partnership Study Visit Programme.

[8] European Union: European Economic and Social Committee 2014, 'EESC recommendations on Social Enterprise', Visits and Publications Unit, Brussel.

[9] Denny, S \& Seddon, 2013, Social Enterprise: Accountability and Evaluation Around the World, Routledge.

[10] Holcomb, \& Fox Parker, 2014, 'Work for the common good: An Introduction to Social Enterprise for Christian Organizations in Canada', JustWork Economic Initiative; World Vision Canada, JustWork Economic Initiative, Vancouver.

[11] Zimbabwe Catholic Bishops Conference 2016, Zimbabwe Catholic Bishops Association, viewed 15 September 2016, <http://www.zcbc.co.zw/catholic-education-commission/>.

[12] CAFOD 2016, CAFOD UK, viewed 17 September 2016, <http://cafod.org.uk/About-us/Where-wework/Africa/Zimbabwe>.

[13] CARITAS 2016, CARITAS Organisation, viewed 16 September 2016, 〈http://www.caritas.org/where-we-are/africa/zimbabwe/>.

[14] Zimbabwe Catholic Bishops Conference 2016, ZCBC, viewed 16 September 2016, <http://www.zcbc.co.zw/caritas/ >.

[15] Kubatana 2013, Kubatana, viewed 2016, $<$ http://archive.kubatana.net/html/sectors/cat005.asp?sector=MICFIN\&details=Tel\&orgcode $=$ cat00 $\underline{5}>$.

[16] Darko, \& Koranteng, 2015, 'Social Enterprise Landscape in Ghana', British Council Ghana, British Council Ghana, British Council Ghana, Ghana. 
[17] Dinham , 2007, 'Faiths \& Frontiers on the Starship Social Enterprise: boldly going as faith based entrepreneurs? ', Kensington Charity Centre, The Faith Based Regeneration Network UK, UK.

[18] Sivov, P 2008, 'The Church as an Agent of Community Development in Bulgaria', Studies in World Christianity, vol 14, no. 3, pp. 214-219.

[19] Williams, T \& Bakam, B 1992, 'The Role of the Church in Community Development: Two Case Studies:- 1) Lawndale Community Church's Community Development Initiatives in North Lawndale; 2) Linwood Shopping Center: The Role of the Church and Community Development Corporations in Community Economic Development', Center for Urban and Regional Affairs, University of Minnesota Minneapolis, Hubert H. Humphrey Institute of Public Affairs.

[20] Dreyer, PF 2004, 'Participatory Development: The role of the church as socio-spiritual role-player in the development of the disadvantaged rural communities in South africa', Department of Agricultural Economics, Extension and Rural Development, University of Pretoria, University of Pretoria, Pretoria.

[21] Ovbiedo, D 2013, 'The role of Christian churches in community development: A case study of Ovia South-west Nigeria', Research, University of South Africa, University of South Africa.

[22] Madise, M 2009, AN APPRAISAL OF ZIMBABWE'S ECONOMIC PERFOMANCE: ISSUES, PROBLEMS AND PROSPECTS, viewed 16 March 2016, $<$ http://marshalmadise.blogspot.com/2009/11/appraisal-of-zimbabwes-economic.htmll .

[23] ZEGU 2016, Zimbabwe Ezekiel Guti University, viewed 16 January 2017, <http://www.zegu.ac.zw/AboutUs/HistoryAndBackground>.

[24] FIFMI 2011, FIFMI, viewed 16 January 2017, <fifmi.org/content/mbuya-dorcas-health-center>.

[25] Floyd, D 2012, 'Why Social Enterprise: A Guide for Charities', Social Enterprise UK.

[26] Lehner, OM 2011, 'The Phenomenon of Social Enterprise in Austria: A Triangulated Descriptive Study', Journal of Social Entrepreneurship, vol 2, no. 1.

[27] Leadbeater, 2007, 'Social enterprise and social innovation: Office of the Third Sector Strategies for the next ten years ', Cabinet Office- Office of the Third Sector 